\title{
Epidemiology of typhoid fever among Students and Staff of tertiary Education institution
}

\author{
Abdullahi ML, Mathiebe JM \\ The University of South Africa (UNISA), South Africa
}

\begin{abstract}
The aim of the study was to assess the epidemiology of typhoid fever among students and staff of a tertiary Educational institution. The study was conducted at a Tertiary Education Institution in Kaura Namoda, Zamfara State, North West Nigeria. It is a tertiary Coeducational institution consisting of students and staff mainly from Northwest Nigeria. Data was collected using a prevalidated modified typhoid and paratyphoid fever questionnaire by considering all possible variables according to information developed on the basis of relevant literature. Four hundred students and 400 staff (all above 18 years) of the polytechnic were drawn using simple random sampling method from a total population of 6222 (sample size calculated using Yamane Method). Quantitative, cross sectional research was conducted to find the determinants of typhoid fever, to also determine whether or not multi-drug resistance to routine antibiotics used in treating typhoid fever exist among the study population, and to develop clinical and public health guidelines for effective management of the disease. The study findings revealed that unsafe drinking water in a form of sachet water is an important vehicle in typhoid fever transmission among the study population. Self-medication and poor vaccination coverage were likely found to be the factors responsible for Multi-Drug Resistance in study samples that show resistance. However, no association was found between the two study groups. At the end of the study, the researcher, with the help of Panel of experts, developed clinical and public health guidelines using Delphi's technique for effective management of typhoid fever within the study setting.
\end{abstract}

Key words: Epidemiology; staff; students; tertiary educational institution; typhoid fever

\section{INTRODUCTION}

$\mathrm{E}$ nteric fever is a systemic infection caused by the humanadapted pathogens Salmonella enterica serotype Typhi ( $S$ Typhi) and S enterica serotype Paratyphi (S Paratyphi) A, B, and $\mathrm{C}$. These organisms are important causes of febrile illnesses in crowded and impoverished populations with inadequate sanitation that are exposed to unsafe water and food and also pose a risk to travellers visiting countries of endemicity (Crump \& Mintz 2010:241).

Global estimates for the burden of typhoid fever (defined as symptomatic infection with $S T$ Typhi) are published regularly (26.9 million cases of typhoid fever were reported in 2010). However, detailed local surveillance data from endemic regions remain poor (Wain, Hendriksen, Mikoleit, Keddy \& Ochiai 2015:1136)

Mortality rates in patients with typhoid fever who are not given specific antibiotics can be as high as $26 \%$, although earlier work described mortality rates of $10 \%$ or lower that were associated with careful management including strict adherence to a milk diet (Wain et al 2015:1139).

The introduction of chloramphenicol (in 1948), ampicillin (1961), co-trimoxazole (1970s), and third-generation cephalosporins and fluoroquinolones, such as ciprofloxacin and ofloxacin (1980s), reduced the mortality of typhoid fever considerably. However, multidrug-resistant strains that were resistant to all three first-line antimicrobial drugs emerged in the 1980s, followed by strains resistant to fluoroquinolones in the 1990s (Wain et al 2015:1139).

In Africa, with the emergence of the S Typhi strains with multidrug resistance and decreased ciprofloxacin susceptibility is now an important issue (Wain et al 2015: 1140).Rates of multidrug resistance vary, for example, $30 \%$ in the Democratic Republic of the Congo, 63\% in Ghana, $70 \%$ in Kenya, and 100\% during an outbreak along the Malawi Mozambique border (Wain et al 2015:1141

Contaminated water and food are important vehicles for the transmission of typhoid fever. Historical surveillance data suggest that enteric fever was endemic in Western Europe and North America and that rate decreased in parallel with the introduction of treatment of municipal water, pasteurisation of dairy products, and the exclusion of human faeces from food production (Crump \& Mintz 2010:242). At present, enteric fever prevention focuses on improving sanitation, ensuring the safety of food and water supplies, identification and treatment of chronic carriers of $S$ Typhi, and use of typhoid vaccines to reduce the susceptibility of hosts to infection (Crump \& Mintz 2010:242).

Similarly, in another research conducted on patients receiving care at a military Hospital in Minna, Niger State, Northwest Nigeria by Adabara, Ezugwu, Momojimoh, Madzu, Hashiimu and Damisa (2012:1) the result showed that isolates of Salmonella typhi were resistant to ceftriaxone, cefixime, amoxicillin, amoxicillin, Ciprofloxacin, and augmentin which are the common drug of choice routinely used in the study area. They were, however, sensitive to ofloxacin and chloramphenicol even though the latter is no longer used for the treatment of typhoid fever on account of an adverse reaction.

In this study context, many patients present to the polytechnic clinic with symptoms of typhoid fever. After confirmation through laboratory investigation, patients undergo treatment 
with first and second line typhoid fever antibiotics. However, most of them only have partial improvement from their initial symptoms. The repeats of Widal and blood culture tests show the presence of typhoid fever.

Therefore, this study intends to find out the determinants of typhoid fever, and whether there is presence of Multidrug Resistance to routine antibiotics used for the treatment Typhoid Fever and its associated factors among the study population.

Lastly, to develop guidelines to influence good clinical and public health policy based on the research findings.

\section{MATERIALS AND METHODS}

\section{Study population}

Research population is defined as a particular group of individuals or elements, who are the focus of research (Burns \& Grove 2011:342). The target population in this study was students and staff (Teachers, and supporting staff) of a Tertiary Education Institution in Kaura Namoda, Zamfara State, North West Nigeria. The polytechnic is a tertiary Coeducational institution offering National Diploma and Higher National Diploma in Engineering, Arctechtural technology, Building technology, Management, science laboratory technology, mathematics, and computer science consisting of students and staff mainly from Northwest Nigeria (Kaduna, Zamfara, Katsina, Kebbi, Sokoto, Kano, Jigawa).

\section{Study context}

The study area in which the students and staff are resident in is Kaura Namoda, a local government area of Zamfara state North West Nigeria. It has an area of $868 \mathrm{Km}$ square and population of about 281,367 (National Population Commission 2006). The town is the Northern railway terminus that links North to South. There is low literacy rate among the people of the area especially women partly due to cultural beliefs.

\section{Ethical considerations}

The study protocol was submitted to the UNISA Higher degree Committee for ethical approval. In addition each respondent was well informed about the aim and potential benefits and risks (similar that of any patient with typhoid fever presenting to a hospital) of the study and their informed consent and confidentiality was ensured. The trained research assistants were educated through a seminar about obtaining informed consent for the purpose of this research. The right to confidentiality was the cornerstone of this research because of the sensitivity of the subject. Therefore, four components of ethics were considered: autonomy, justice, beneficence, nonmaleficence were taken into consideration throughout the study.

Simple random sampling
In this sampling technique all possible subsets of the population are given an equal probability of being selected (Anol 2012:67).

The study sample was calculated using the YAMANE method (Singh 2014:15) that is

$\mathrm{n}=\mathrm{N} / 1+\mathrm{N}(\mathrm{e})^{2}$

Where $\mathrm{n}$ is the sample size, $\mathrm{N}$ is the population size, and e is the margin of error taken at $50 \%$.

Therefore,

$\mathrm{N}=4122$ for students and $\mathrm{N}=2100$ for staff

$\mathrm{n}=4122 / 1+4122(0.05)^{2}$

$\mathrm{n}=4122 / 1+4122(0.0025)$

$\mathrm{n}=4122 / 1+10.305$

$\mathrm{n}=4122 / 11.305$

$\mathrm{n}=364.617$ approximately $\mathrm{n}=365$ students

Hence, 365 students was required as a minimum sample for the study.

For staff, $\mathrm{N}=2100$

Therefore,

$\mathrm{n}=2100 / 1+2100(0.0025)$

$\mathrm{n}=2100 / 6.25$

$\mathrm{n}=336$ staff was required minimum sample for the study

Hence, in a total population of 6222 (comprising of 4122 students and 2100 staff) 400 students and 400 staff were selected using simple random sampling respectively.

Source for the population size was from the health insurance registration which is mandatory for all students and staff.

\section{STUDY DESIGN}

A quantitative design was chosen since the study used measurable variables using a systematic way of investigation to explain, predict, and control typhoid fever among the study population.

The study was carried out in three phases. In two phases, quantitative data was collected, analysed, and interpreted to answer the research hypothesis.

\section{Data collection method}

The researcher collected data by use of self-administered questionnaires with the help of research assistants in cases where the respondents need guidance in understanding questions (Annexure D). A self-administered questionnaire offers an advantage of an increased response rate. It is cost effective and allows a researcher to assist those who cannot read (Debois 2016:2). 
A Pilot study was conducted by the researcher in a group of students and staff other than the targeted sample at the Federal polytechnic clinic, Kaura Namoda, between November to December, 2017. The outcome of the pilot study show high incidence of typhoid fever with moderate resistance to commonly used antibiotics for empirical therapy (ciprofloxacin and Amoxicillin).

The questionnaire was distributed to the students and staff by ten trained field workers each having at least a Diploma in Medical/science laboratory technology after explaining to them the aim of the study. Those who need assistance were guided by the research assistants.

Research assistants refers here to those whose main role is face-to-face engagement with participants, who usually speak the participants' first language, who are from or live in the study areas, and whose work entails moving around the study areas or health facilities (Molyneux, Kamuya \& Madiega 2013:1).

In the context of this study, the research assistants were ten in number each having at least a National Diploma in Medical/science laboratory technology. Closed ended selfadministered questionnaires were distributed to the study sample by the researcher assisted by the research assistants between January to May, 2018. The study population were randomly selected from patients (Staff and Students) presenting at the polytechnic clinic, Kaura Namoda, with suspected cases of typhoid fever.

The research assistants explained to participants the purpose of the study, obtained informed consent, and guided the participants in answering the questionnaire where necessary. The research assistants also helped in obtaining results of the Widal test as well as blood culture and sensitivity tests and kept records of it appropriately.

The questionnaire has two parts.

The first part assessed the determinants and outcome of typhoid fever/Multi-drug Resistance Typhoid Fever among the study population. This was achieved through the answers given by the respondents using a pre-validated questionnaire. The answers from the questionnaire were used to determine the factors leading to the development of typhoid fever/ Multidrug Resistance Typhoid Fever and the appropriate public health policy and clinical practice needed to influence policy.

The second part determined the incidence of Multi-drug Resistance Typhoid Fever among the study population. The Widal test, blood culture and sensitivity test were used to determine the presence or absence of typhoid fever as well as the sensitivity profile of the Salmonella $\mathrm{spp}$ to the recommended first and second line drugs used for treating typhoid fever.

The data collection setting was a comprehensive primary health facility which provides medical and surgical care to staff and students of the polytechnic. The facility has a functional medical laboratory that runs microbiological, haematological, and chemical pathology tests. It has a male, female, maternity, and amenity wards. It also has a labour room, theatre room, injection room and a dressing room. Other structures are the National Health Insurance Scheme (NHIS) office, consulting rooms, nursing stations, pharmacy unit, medical record unit and staff offices.

Blood sample for the Widal test and blood culture and sensitivity test were taken through venepuncture by 4 trained phlebotomists at a medical laboratory of the polytechnic clinic. The Widal test was performed by laboratory technicians working at the laboratory unit of the federal Polytechnic, Kaura Namoda, using the Widal test reagent from AGAPE®. The results from the Widal test were confirmed by the laboratory scientist. The minimum inhibitory concentration of antibiotics used in order to determine sensitivity pattern using Mueller Hinton agar by dose diffusion method using the National committee for clinical laboratory standard manual of antimicrobial susceptibility testing were (NCCLS 2005:339) Ampicillin $10 \mu \mathrm{g} / \mathrm{disc}$, cotrimoxazole $25 \mu \mathrm{g} / \mathrm{disc}$, ciprofloxacin $5 \mu \mathrm{g} / \mathrm{disc}$, ceftriaxone $\quad 30 \mu \mathrm{g} / \mathrm{disc}$ azithromycin $15 \mu \mathrm{g} / \mathrm{disc}$, chloramphenecol $30 \mu \mathrm{g} / \mathrm{disc}$.

The results from the blood culture and sensitivity test were used to determine the rate of occurrence of new cases of typhoid fever as well as if there is emergence of Multidrug resistance typhoid fever within the study population.

\section{RESULTS}

Phase 1

\section{Age distribution}

The sample of 800 respondents (400 students and 400 staff) was composed of $308(77.00 \%)$ students and $23(5.75 \%)$ staff respondents aged between 18-24, $63(15.75 \%)$ students and 55 $(13.00 \%)$ staff respondents were aged 25-31, while 21 $(5.25 \%)$ students and $138(34.50 \%)$ of the respondents were aged between $32-38$ years respectively. Eight $(2.00 \%)$ of the students and $187(46.75 \%)$ of the staff respondents were aged between 39 and 45 .

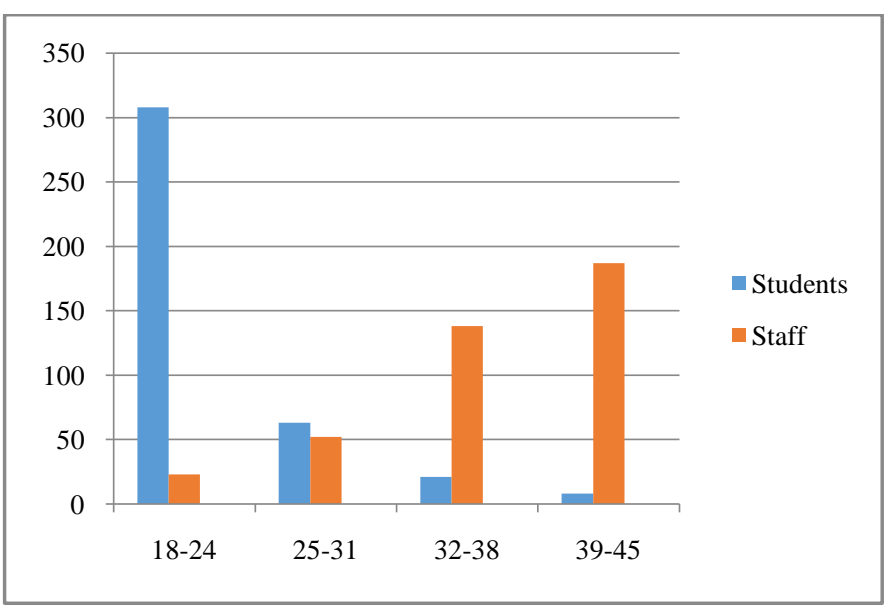

Figure 1.0 Age distribution (Students N=400) (Staff N=400) 


\section{Sex distribution}

Out of the total 400 student respondents, Male respondents account for $72.00 \%$ which is higher than female respondents which account for $28.00 \%$. Male staff respondents were $79.00 \%$, while female staff respondents were $21.00 \%$.

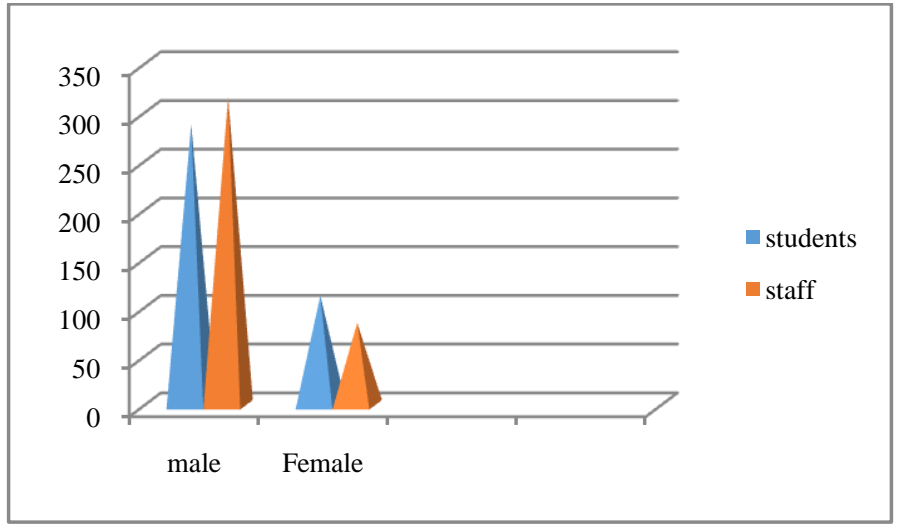

Figure 1.1 Sex distribution (Students $\mathrm{N}=400)($ Staff N=400)

\section{Location}

Three hundred and seven $(76.75 \%)$ of the study students population reside on campus, while 93 (23.25\%) reside off campus. Four hundred (100\%) of the staff respondents reside off campus.

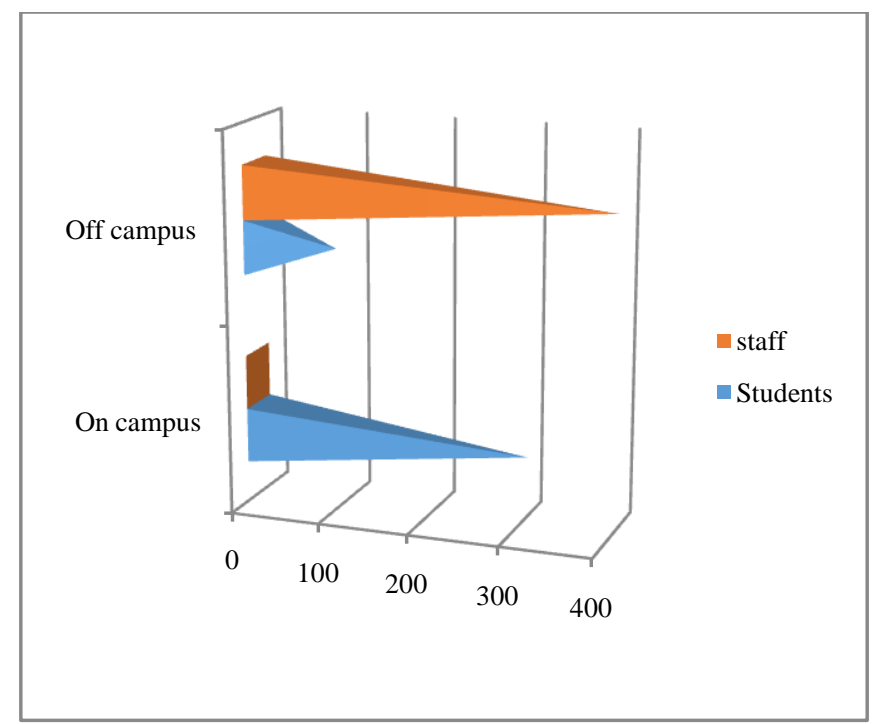

Figure 1.2 Location (Students N=400) (Staff N=400)

Source of drinking water

Sachet water was the major source of drinking water for the respondents accounting for $228(57.00 \%)$ for students and 312 $(78.00 \%)$ for staff respectively, Bore hole water was the source of drinking water for $149(37.25 \%)$ of the students respondents and $64(16.05 \%)$ of staff respondents respectively. Twenty $(5.00 \%)$ and one $(0.25 \%)$ of the students respondents rely on tap water and bottled water for drinking respectively. Only six $(1.50 \%)$ and five $(1.25 \%)$ of the staff respondents drink tap and bottled water respectively.

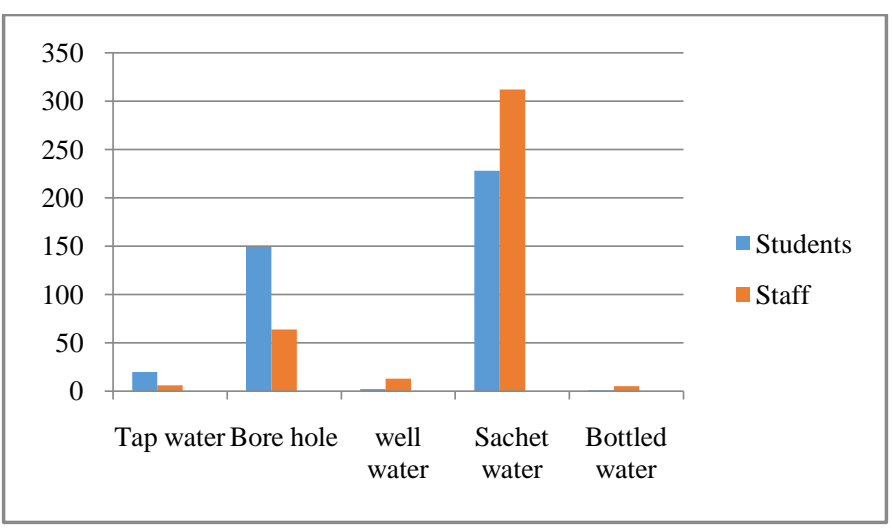

Figure 1.3 Source of drinking water (Students N=400) (Staff N=400)

\section{Self-medication}

Three hundred and fourteen $(78.50 \%)$ of the student respondents admitted that they took self-medication before reporting to the hospital while $86(21.50 \%)$ admitted that they did not take self-medication. Three hundred and seventy $(92.50 \%)$ of the staff respondents took self-medication before reporting to hospital while $30(7.50 \%)$ did not take selfmedication.

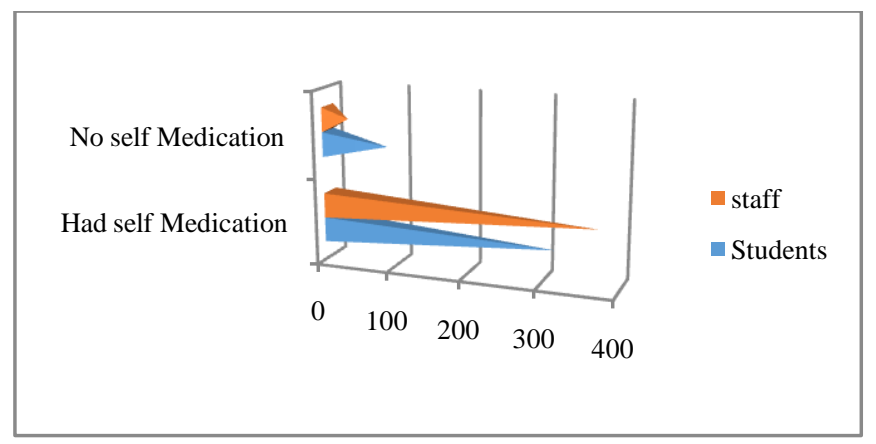

Figure 1.4 Self-medication (Students N=400) (Staff N=400)

\section{Vaccination history}

Only $3(0.75 \%)$ of the student respondents had been vaccinated against typhoid fever while 397 (99.25\%) did not ever had vaccination against typhoid fever. Three hundred and eighty six $(96.50 \%)$ of staff respondents had never been vaccinated against typhoid fever while only $14(3.50 \%)$ of the staff had been vaccinated.

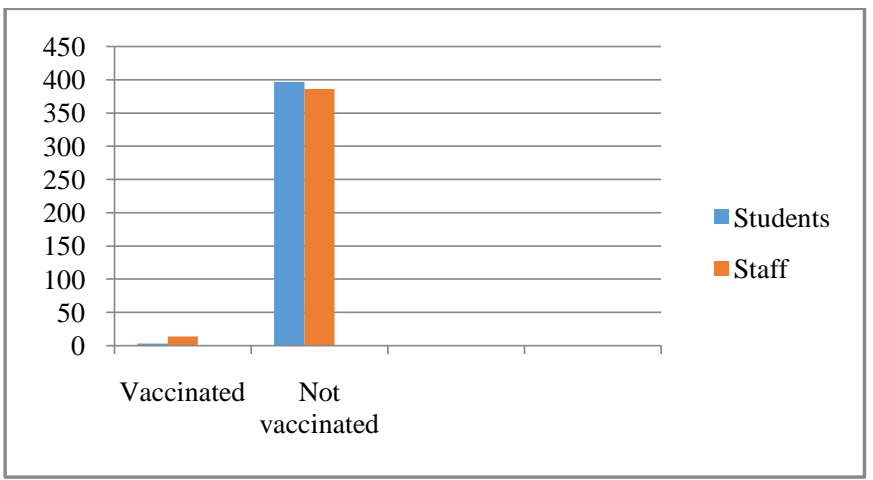

Figure 1.5 Vaccination history (Students $\mathrm{N}=400)(\mathrm{Staff} N=400$ ) 


\section{Clinical presentation}

Fever was the highest clinical presentation by the respondents $336(84.00 \%)$ for students and $318(79.50 \%)$ for staff, 312 $(78.00 \%)$ of students and $278(69.50 \%)$ of staff presented with headache, $328(82.00 \%)$ of students and $213(53.25 \%)$ of staff presented with abdominal pain, $234(58.50 \%)$ of students and $103(23.75 \%)$ of staff presented with vomiting, and 136 $(34.00 \%)$ of students and $88(22.00 \%)$ of staff reported with diarrhoea.

Table 1.1Clinical presentation

\begin{tabular}{|c|c|c|c|c|}
\hline \multirow{2}{*}{ Symptom } & Frequency & Percentage & Frequency & Percentage \\
\hline & \multicolumn{2}{|c|}{ Students } & \multicolumn{2}{|c|}{ Staff } \\
\hline Fever & 336 & 84.00 & 318 & 79.50 \\
\hline Vomiting & 234 & 58.50 & 103 & 23.75 \\
\hline Headache & 312 & 78.00 & 278 & 69.50 \\
\hline Abdominal pain & 328 & 82.00 & 213 & 53.25 \\
\hline Diarrhea & 136 & 34.00 & 88 & 22.00 \\
\hline Constipation & 45 & 11.25 & 12 & 3.00 \\
\hline Cough & 110 & 27.50 & 84 & 21.00 \\
\hline Rash & 4 & 1.00 & 0 & 0 \\
\hline Rigors & 22 & 5.50 & 7.00 & 1.75 \\
\hline Asymptomatic & 8 & 2.00 & 3 & 0.75 \\
\hline
\end{tabular}

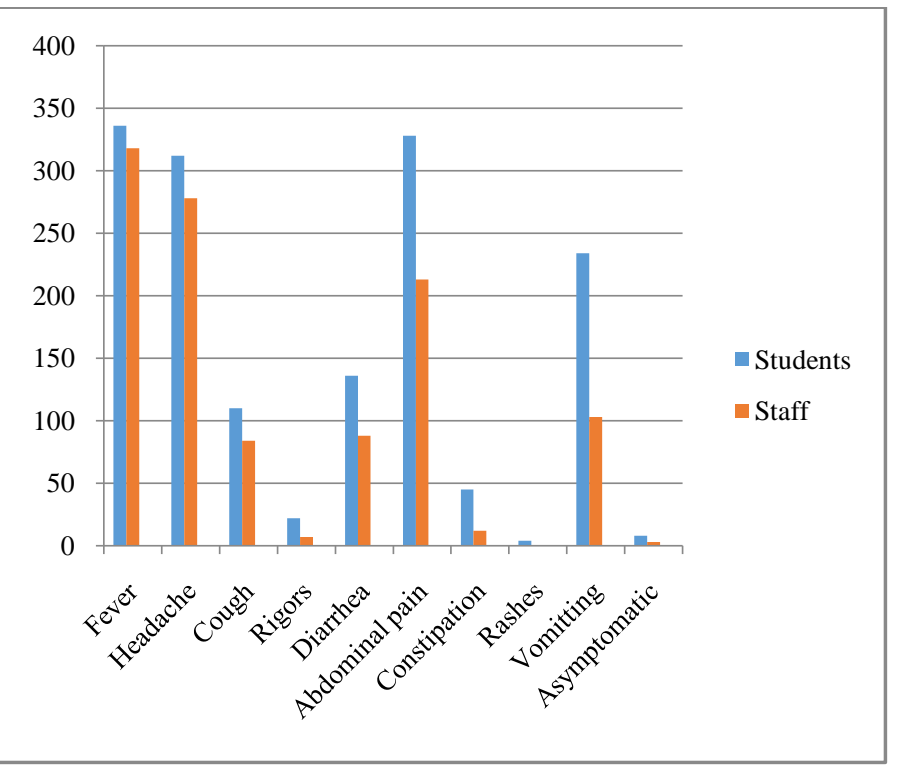

Figure 1.6 Clinical presentation (Students $\mathrm{N}=400$ ) (Staff $\mathrm{N}=400$ )

Phase 2

\section{RESULT OF WIDAL TEST}

Three hundred and sixty eight $(92.00 \%)$ of the 400 student respondents have significant titre while $32(8.00 \%)$ of the respondents have titre that is not significant. Three hundred and forty three $(85.75 \%)$ of the staff respondents had significant Widal test result while 57 (14.25\%) have Widal test that was not significant.
Table 1.2 Widal test result

\begin{tabular}{|c|l|l|l|l|}
\hline $\begin{array}{c}\text { Widal } \\
\text { test } \\
\text { result }\end{array}$ & $\begin{array}{c}\text { Frequency } \\
\text { Students }\end{array}$ & $\begin{array}{c}\text { Percentage } \\
\text { Students }\end{array}$ & $\begin{array}{c}\text { Frequency } \\
\text { Staff }\end{array}$ & $\begin{array}{c}\text { Percentage } \\
\text { Staff }\end{array}$ \\
\hline $\begin{array}{c}\text { Significa } \\
\text { nt titre }\end{array}$ & 36 & 92.0 & 34 & 85.7 \\
& 8 & 0 & 3 & 5 \\
\hline $\begin{array}{c}\text { Not } \\
\text { Significa } \\
\text { nt }\end{array}$ & 32 & 8.0 & 57 & $\begin{array}{c}14.2 \\
5\end{array}$ \\
\hline
\end{tabular}

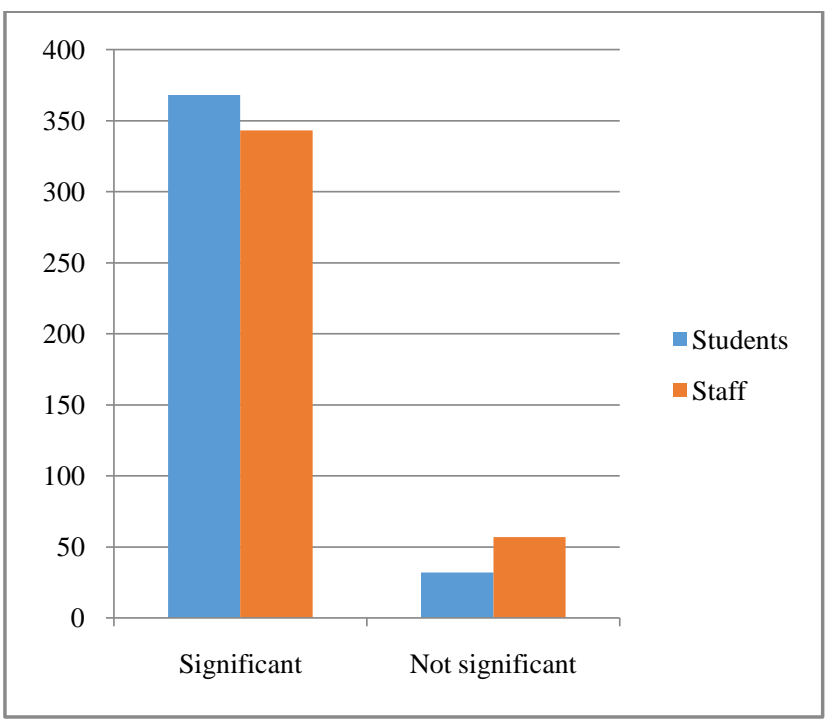

Figure 1.7 Widal test result (Students $\mathrm{N}=400)(\mathrm{Staff} N=400$ )

Antibiotic sensitivity and resistance pattern for Salmonella typhi and Salmonella para typhi among students and staff 
Ceftriaxone has the highest sensitivity pattern as all the 400 $(100 \%)$ students' samples and $396(99.00 \%)$ of staff samples were sensitive to it.

$351(87.75 \%)$ of student's sample and $312(78.00 \%)$ of staff sample were sensitive to cefixime, $214(53.50 \%)$ of student's sample and $112(28.00 \%)$ of staff sample were sensitive to Ciprofloxacin, 303(75.75\%of student's sample and 301 $(72.25 \%)$ of staff sample were sensitive to chloramphenecol,
$159(39.75 \%)$ of student's sample and $196(49.00 \%)$ of staff sample were sensitive to Azithromycin .

One hundred and thirteen (28.25\%) student' sample and 83 $(20.75 \%)$ staff sample were sensitive to Amoxicillin, while only $41(10.25 \%)$ of the student's sample and $23(5.75 \%)$ of staff sample was sensitive to Cotrimoxazole.

Table 1.3 Antibiotic sensitivity and resistance pattern for Salmonella typhi and Salmonella para typhi among students and staff

\begin{tabular}{|c|c|c|c|c|}
\hline \multirow[b]{2}{*}{ Antibiotic } & Frequency & Percentage & Frequency & Percentage \\
\hline & \multicolumn{2}{|c|}{$\begin{array}{l}\text { Students } \\
\text { Sensitive }\end{array}$} & \multicolumn{2}{|c|}{$\begin{array}{c}\text { Students } \\
\text { Resistance }\end{array}$} \\
\hline Ceftriaxone & 400 & 100.00 & 0 & 0 \\
\hline Cefixime & 352 & 87.75 & 49 & 12.25 \\
\hline Chloramphenecol & 303 & 75.75 & 97 & 24.25 \\
\hline Ciprofloxacin & 214 & 53.50 & 186 & 46.50 \\
\hline Azithromycin & 159 & 39.75 & 241 & 60.25 \\
\hline Amoxicillin & 113 & 28.25 & 287 & 71.75 \\
\hline Cotrimoxazole & 41 & 10.25 & 359 & 89.75 \\
\hline \multirow[b]{2}{*}{ Antibiotic } & Frequency & Percentage & Frequency & Percentage \\
\hline & \multicolumn{2}{|c|}{$\begin{array}{c}\text { Staff } \\
\text { Sensitive }\end{array}$} & \multicolumn{2}{|c|}{$\begin{array}{c}\text { Staff } \\
\text { Resistance }\end{array}$} \\
\hline Ceftriaxone & 396 & 99.00 & 4 & 1.00 \\
\hline Cefixime & 312 & 78.00 & 88 & 22.00 \\
\hline Chloramphenecol & 301 & 75.25 & 99 & 24.75 \\
\hline Ciprofloxacin & 112 & 28.00 & 288 & 72.00 \\
\hline Azithromycin & 196 & 49.00 & 204 & 51.00 \\
\hline Amoxicillin & 83 & 20.75 & 317 & 79.25 \\
\hline Cotrimoxazole & 23 & 5.75 & 377 & 94.25 \\
\hline
\end{tabular}

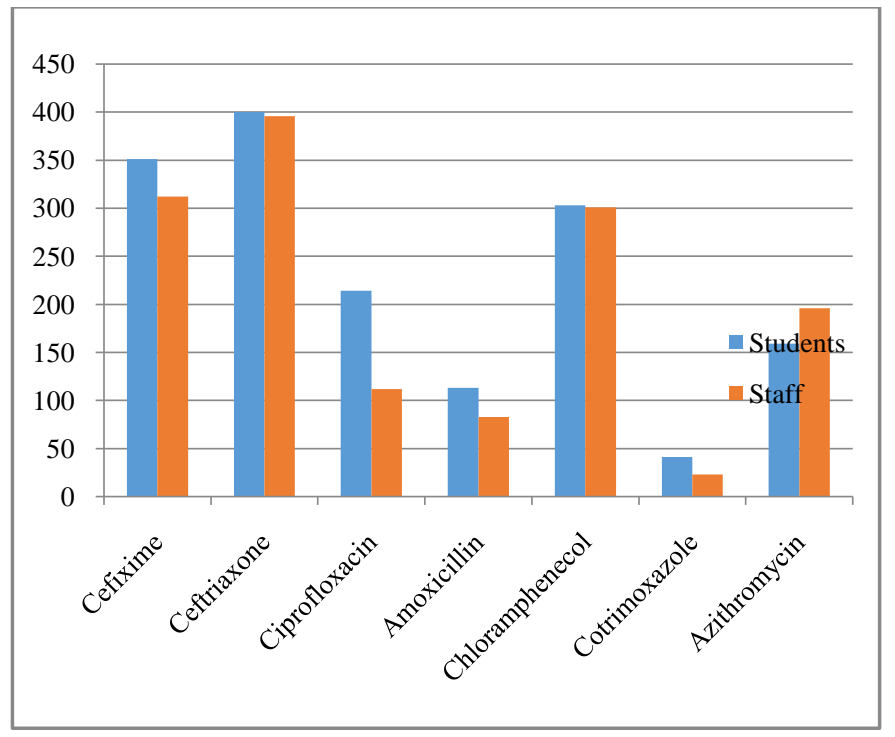

Figure 1.8 Antimicrobial sensitivity pattern to $S$ Typhi and S Paratyphi (Students N=400) (Staff N=400)

\section{Hospital Admission}

Out of the 400 student respondents, 22 (5.50\%) were admitted to the school health centre for treatment, while 378 (94.50\%) were treated as outpatients. Similarly, 19 (4.75\%) of the staff were admitted for treatment while $381(95.25 \%)$ of staff were treated as outpatient.

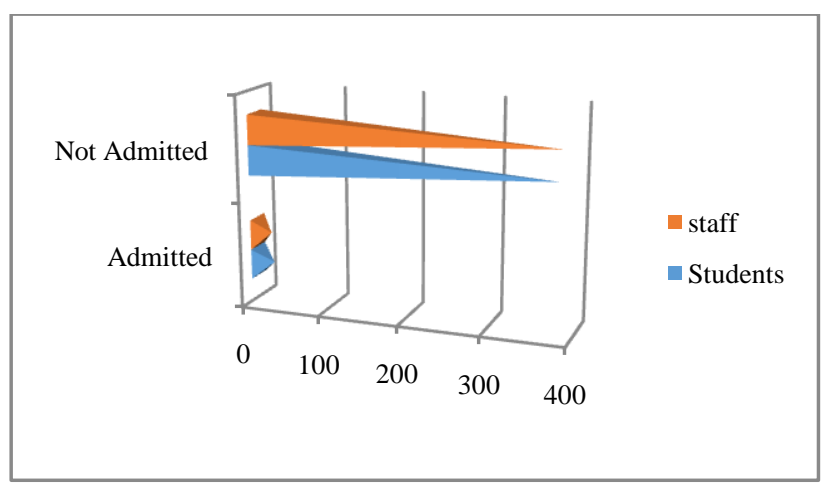

Figure 1.9 Hospital admission (Students $\mathrm{N}=400)(\mathrm{Staff} N=400)$ 


\section{Preliminary Antibiotic given for treatment}

Chloramphenecol was the highest preliminary antibiotic treatment given, accounting for $180(45.00 \%)$ for students and $211(52.75 \%)$ for staff prior to the result of blood culture and sensitivity test. Ceftriaxone was given to $15(3.75 \%)$ of students and 22(5.50\%) of staff, Azithromycin 14 (3.50\%) for students and $47(11.75 \%)$ for staff, Amoxicillin $68(17.00 \%)$ for students and $25(6.25 \%)$ for staff, Ciprofloxacin 110 $(27.50 \%)$ for students and $95(23.75 \%)$ for staff, and Cotrimoxazole $13(3.35 \%)$ for students and none (0) for staff.

Table 1.4 Preliminary antibiotic treatment

\begin{tabular}{|c|c|c|c|c|}
\hline \multirow{2}{*}{ Antibiotic } & Frequency & Percentage & Frequency & Percentage \\
\hline & \multicolumn{2}{|c|}{ Students } & \multicolumn{2}{|c|}{ Staff } \\
\hline Ceftriaxone & 15 & 3.75 & 22 & 5.50 \\
\hline Chloramphenecol & 180 & 45.00 & 211 & 52.75 \\
\hline Ciprofloxacin & 110 & 27.50 & 95 & 23.75 \\
\hline Azithromycin & 68 & 17.00 & 25 & 6.25 \\
\hline Amoxicillin & 14 & 3.50 & 47 & 11.75 \\
\hline Cotrimoxazole & 13 & 3.25 & 0 & 0.00 \\
\hline
\end{tabular}

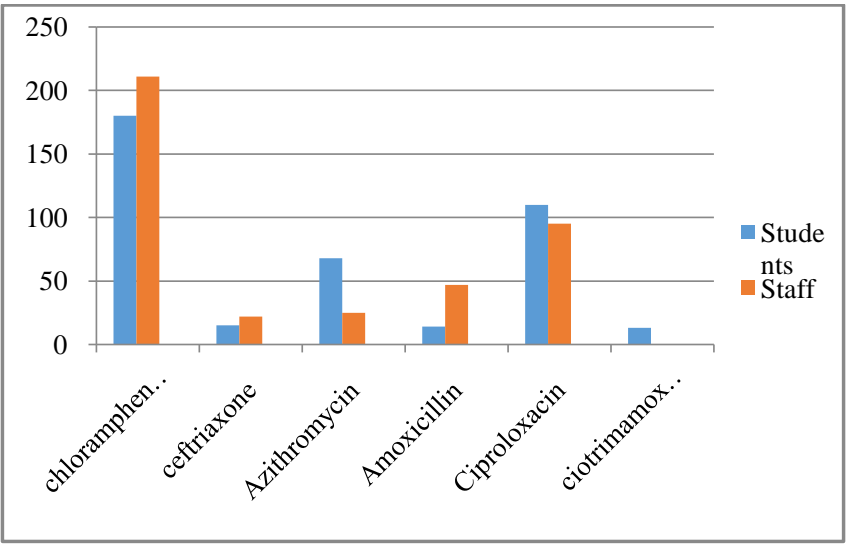

Figure 1.10 Preliminary anti biotic treatment

(Students $\mathrm{N}=400)$ (Staff $\mathrm{N}=400)$

\section{DISCUSSION}

\section{Age distribution}

The predominant age group was 18-24 (77.00\%) among students while the predominant age group among staff was $39-45$ accounting for $48.75 \%$. This could be attributed to the fact that the study was carried out in an Educational institution where students within the age group of 18-24 are found. This is in line with another study carried out in a college of Education clinic, Akwanga, Nasarawa state, North central Nigeria, where the age range having the highest prevalence of typhoid fever for a 3 year period $(2005,2006,2007)$ were those between 21-30 year age group.

\section{Sex distribution}

Male respondents were higher than the female respondents, $59.5 \%$ and $40.5 \%$ respectively. This could be due to cultural beliefs in most communities in Africa where girl child Education is considered unimportant. Therefore, their enrolment in schools is low accounting for higher number of male compared to female respondents in this study (schoolbased).

In $2011,8.3 \%$ of female were enrolled in tertiary Education in Nigeria compared to $11.76 \%$ male enrolment (UNESCO 2013).

\section{Location}

Of the student respondents, $76.75 \%$ were residing on campus while only $23.25 \%$ of them reside off campus. All staff respondents reside off campus because no accommodation is made available to them on campus. Considering the fact that the study was carried out among staff and students where all staff and some students reside off campus, it is not surprising that the highest number of respondents were residing off campus. This is in agreement with a study carried out to determine the satisfaction level of hostel facilities in Nigerian Polytechnics which shows a $66.6 \%$ student dissatisfaction level (Sawyerr \& Yusof 2013:306).

\section{Source of drinking water}

The highest proportion of respondents (both students and staff) used sachet water as their source of drinking water accounting for $57.00 \%$ and $78.00 \%$ for students and staff respectively. In almost all parts of Nigeria, sachet table water prepared by small-scale entrepreneurs using sealed polythene bag for storage after simple purification method, is being used as source of drinking water. The small-scale entrepreneurs need to undergo evaluation of their factories for suitability of production by National Agency for Food, Drugs, Administration and Control (NAFDAC) after which they are registered for production and consumption. However, some of the factories produce their sachet water without certification by NAFDAC. Therefore, it is possible for some of the respondents to consume this type of sachet water. NAFDAC, as an enforcement agency, need to checkmate these water 
production factories regularly (without notice) to ensure safety of the general public.

Borehole water was the second largest source of drinking water for both students and staff accounting for 37.255 and $16.00 \%$ respectively. This is being drilled by individuals who sold the water from it to water vendors in 25 litres gallons. Some of the water vendors keep their gallons in an unhygienic manner making their water not safe for consumption.

About 70 million Nigerians out of 171 million lacked access to safe drinking water in 2013. Many schools in Nigeria also lack private toilets and safe hand washing facilities (UNICEF 2013).

\section{Paired t test}

Statistical significance: false

$\mathrm{P}=1.0$

Calculated t Value $=0.0$

Critical t Value $=2.7764$

Table 1.5 Paired student $\mathrm{t}$ test for source of drinking water

\begin{tabular}{|c|c|c|}
\hline & Students & Staff \\
\hline Mean & 80.0 & 80.0 \\
\hline SD & 103.1867 & 131.9754 \\
\hline SEM & 46.1465 & 59.0212 \\
\hline 95\% CI of mean $(-48.12)-(208.12)$ & $(-83.87)-(243.87)$ \\
\hline N & 5 & 5 \\
\hline
\end{tabular}

\section{Self-medication}

Of the student respondents, $78.50 \%$ took medication before reporting to Hospital while only $21.50 \%$ of them did not take medication before reporting to hospital. A percentage of $92.50 \%$ of staff took self medication prior to reporting to Hospital while only $7.50 \%$ did not. Internationally self medication is the most common and obvious contributing factor to antibiotic resistance (Rather, Kim, Vivek, Bajpai \& Park 2017:808-812). This act of self-medication could be a factor that contributes to antimicrobial resistance in this study.

\section{Vaccination history}

Vaccination is the single most important strategy in controlling the spread of infectious diseases. In this study, only $0.75 \%$ and $3.50 \%$ of the students and staff respondents were vaccinated against typhoid fever respectively. Among them none was vaccinated for a booster dose (live typhoid vaccine) within the last five years (CDC 2017). This shows the lack of typhoid fever vaccination coverage which may contribute to the spread of the disease within the polytechnic community.

\section{Clinical presentation}

Fever, abdominal pain, and headache were the highest symptoms reported by the student respondents accounting for
$84.00 \%, 82.00 \%$, and $78.00 \%$ respectively. While the staff predominant symptoms are fever $79.50 \%$, headache $69.50 \%$, and abdominal pain $53.75 \%$.Headache is the second most presenting symptom in staff while abdominal pain is the second most presenting symptom in students. These symptoms are none specific to typhoid fever. Misdiagnosis therefore, could easily be done without appropriate investigation. Many cases of typhoid fever are missed or misdiagnosed as malaria due to the non-specificity of these symptoms (Onyekwere 2007:76-79).

Misdiagnosis of typhoid fever might lead to improper treatment which in turn results in worsening of symptoms and manifestation of complications (Onyekwere 2007:76-79).

Paired t test

Statistical significance: true

$\mathrm{P}=0.0078$

Calculated $\mathrm{t}$ Value $=-3.4039$

Critical t Value $=2.2622$

Table 1.6 Paired student $\mathrm{t}$ test for clinical presentation

\begin{tabular}{|c|c|c|}
\hline & Students & Staff \\
\hline Mean & 153.5 & 118.6 \\
\hline SD & 137.4944 & 120.9262 \\
\hline SEM & 43.4796 & 38.2402 \\
\hline 95\% CI of mean $(55.14)-(251.86)$ & $(32.09)-(205.11)$ \\
\hline N & 10 & 10 \\
\hline
\end{tabular}

\section{Widal test result}

Of the student respondents, $92.00 \%$ have significant titre while $8.00 \%$ have titre that is not significant. Of the staff respondents, $87.75 \%$ have significant titre, while $14.25 \%$ have titre that is not significant. The higher number of significant titre among students compared to staff could be as result of water and food consumed by the students which have low hygienic status compared to that consumed by staff. This is because students most often patronise roadside food vendors for feeding where the food and water is questionable. This is in agreement with a study carried out at a Tertiary Education Institution at Akwanga, Nasarawa state, North central, Nigeria, in which $73 \%$ of the students have significant Widal titre with the likely implicating factors being consumption of unhygienic food and drinks like cow milk, sobo (hibiscus) and patronage of food vendors (Ishaleku, Sar \& Houmsou 2011:139).

\section{Antibiotic sensitivity pattern}

Ceftriaxone, cefixime, chloramphenecol, and ciprofloxacin were antibiotics with the highest sensitivity profile among students accounting for $100 \%, 87.75 \%, 75.75 \%$, and $53.50 \%$ respectively, while ceftriaxone $(99.00 \%)$, cefixime $(78.00 \%)$, chloramphenecol $(75.25 \%)$, and azithromycin (49.00\%) has the highest sensitivity pattern among staff. The antibiotics 
used for empirical therapy were chloramphenecol, ciprofloxacin, and amoxicillin. Therefore, ceftriaxone was not used. It is known that for Multidrug resistant typhoid fever (MDRTF), ceftriaxone and ciprofloxacin can be combined for treatment (Brusch 2018:6). This is in agreement with a study on antibiotic susceptibility pattern of Salmonella typhi and para typhi in a tertiary care hospital where resistance was found in trimethoprim sulphamethoxazole, and amoxicillin, while chloramphenecol had $100 \%$ sensitivity (Poudel, Shrestha, Pradhan, Akpota \& Mahato 2014:1-4).

Azithromycin show intermediate sensitivity $(49.00 \%)$ for staff. This antibiotic has not been used for empirical therapy in this study population. This is in line with a study in which $46 \%$ of the blood culture samples were sensitive while $21 \%$ shows intermediate sensitivity (Choudhary, Gopalakrishnan, Nambi, Ramasubramanian, Abdulghafur \& Thirunarayan 2013:800-802).

The susceptibility pattern of ceftriaxone, ciprofloxacin, chloramphenecol, and azithromycin in this study shows that these drugs are still useful in treatment of typhoid fever. Combination therapy could also boost chances of recovery from typhoid fever. Ceftriaxone was highly sensitive, thus its use could be advocated in this setting especially in severe and suspected MDRTF.

\section{Hospital admission}

Of the student respondents, $94.50 \%$ were treated as outpatients and $5.50 \%$ were treated as in patients while $95.25 \%$ of staff was treated as out-patients and $4.75 \%$ were treated as in-patients. Although most cases of typhoid fever present as uncomplicated, it is important to keep serious cases for observation at least pending the outcome of the investigation (blood culture) as it has been observed that most admitted patients respond well to treatment and improve within 3-5 days, but may take several weeks before discharge (NHS 2018)

\section{Preliminary antibiotic treatment}

The majority of the study population were given empirical treatment with chloramphenecol $(45.00 \%)$ for students and $(52.75 \%)$ for staff, ciprofloxacin $(27.50 \%)$ for students and $(23.75 \%)$ for staff, amoxicillin $(17.00 \%)$ for students and $6.25 \%$ for staff. It is known that there has been multi-drug resistance to most first line drugs used for the treatment of typhoid fever as reported in a study where ciprofloxacin and Amoxicillin were resistant while Chloramphenecol was 100\% sensitive (Poudel et al 2014:1-4). This shows that chloramphenecol may still be useful in treatment of typhoid fever.

\section{Paired t test}

Statistical significance: false

$\mathrm{P}=1.0$

Calculated $\mathrm{t}$ Value $=0.0$
Critical t Value $=2.5706$

Table 1.7 Paired student $\mathrm{t}$ test for preliminary antibiotic treatment

\begin{tabular}{|c|c|c|}
\hline & Students & Staff \\
\hline Mean & 66.667 & 66.667 \\
\hline SD & 67.8931 & 77.714 \\
\hline SEM & 27.7172 & 31.7266 \\
\hline 95\% CI of mean $(-4.58 .83)-(137.92)(-14.89)-(-148.22)$ \\
\hline N & 6 & 6 \\
\hline
\end{tabular}

DEVELOPEMENT OF CLINICAL AND PUBLIC HEALTH GUIDELINE USING DELPHI TECHNIQUE

Ten expert (10) panel were chosen for the development of the guideline comprising of four (4) medical doctors, two (2) laboratory scientists, two (2) senior nurses (Chief nursing officers), and two (2) pharmacists . None of them was informed by the researcher about the involvement of the other so as to remove bias.

Twenty-five (25) statements were circulated to the members of the expert panel using open-ended questionnaires developed by the researcher after reviewing the study for round one (1) voting. They were asked to agree or disagree with the statements.

\section{Round 1}

Twenty five (25) statements were circulated to the expert panel for round one voting with anonymity of the panel members maintained by not disclosing their identities among themselves.

After voting ended for round one (1), ten (10) statements were accepted without modifications while fifteen (15) statements did not reach consensus. At the end of the round, ten (10) statements were incorporated into the final document (figure 1.11). The result at the end of round one (1) was circulated to the panel experts but no face to face discussion was held.

\section{Round 2}

At the beginning of round two (2), fifteen (15) statements were circulated to panel members for the $2^{\text {nd }}$ round of voting. Three (3) statements were accepted without modifications, ten (10) statements were omitted, while two (2) statements did not reach consensus. At the end of the round, three (3) statements were incorporated in to the final document (figure 1.11). The result at the end of round two (2) was circulated to the panel experts but no face to face discussion was held.

\section{Round 3}

Panel members were invited for discussion and ratification of the final consensus document. At the beginning of this round, two (2) statements were presented for discussion, one (1) statement was accepted without modification, one (1) new statement was developed, and one (1) was omitted. At the end of round three (3), two (2) statements were incorporated in to the final document (figure 1.11). 
At end of discussion by the panel members, fifteen (15) consensus statement documents was unanimously agreed comprising of five (5) domains; screening, investigation, physical examination, treatment, and public health intervention. Each of these was paired with matching consensus statements (table 1.11).

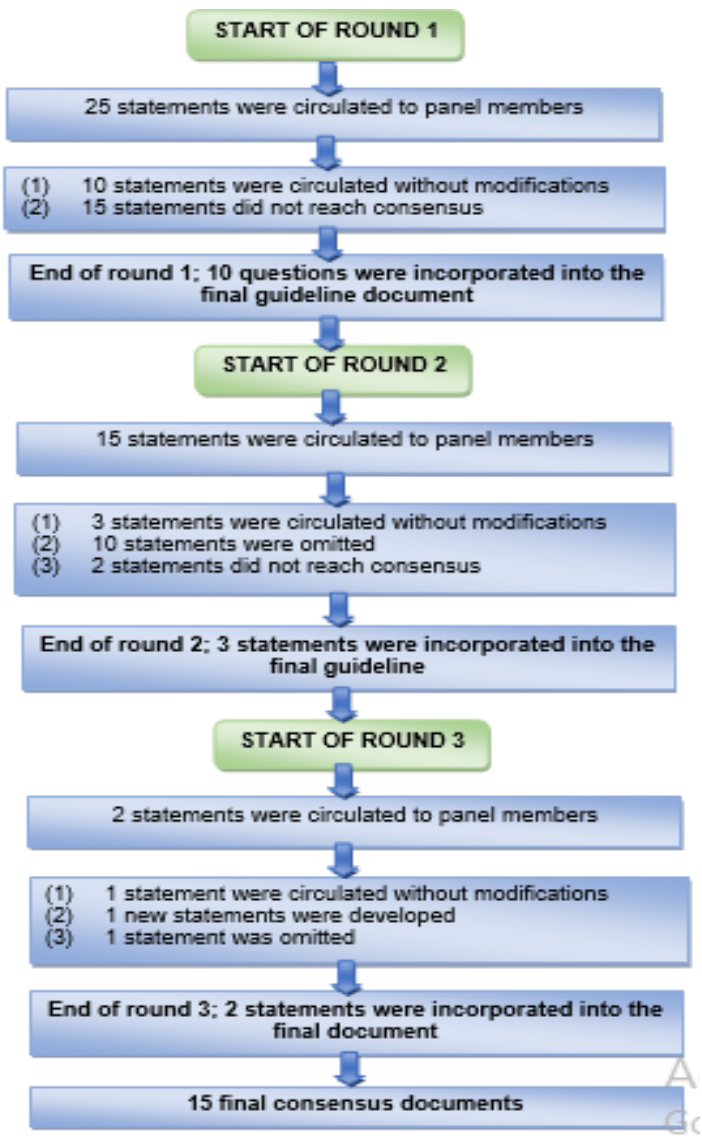

Figure 1.11 Schematic design of Delphi technique used in developing guideline

Clinical and public health guideline for the diagnosis, treatment and prevention of typhoid fever

Clinical and public health guidelines for the diagnosis, treatment, and prevention of typhoid fever

The consensus of the expert panel was that the patient needs to be screened thoroughly for typhoid fever by asking the following questions during history-taking (table 5.1).

- Ask for residence of student

- Ask for source of drinking water

- Ask for proper toilet facility

- Does he/she patronise food vendors

- Ask for clinical symptoms; Fever, abdominal pain, vomiting, loose watery stool, headache

The minimum laboratory investigations should include;

- Felix Widal test

- Malaria parasite test
- Blood culture and sensitivity test when suspicious of MDRTF

The student or staff should be physically examined by performing interventions as reflected in Table 5.1

- Thorough inspection

- Measuring of temperature

- Abdominal examination

The treatment of the student or staff begin with empirical therapy using the following antibiotics (table 5.1)

- Cefixime

- Chloramphenecol

- Ciprofloxacin or other flouroquinolones

- Azithromycin

Specific antibiotic sensitive drug should be used from the result of blood culture and sensitivity if there is no response to empirical therapy.

The following advice with regard to public health intervention should be given before discharging the patient to prevent reoccurrence and MDRTF:

- Advice on consumption of safe and clean drinking water and food

- Avoidance of self-medication

- Recommend typhoid fever vaccination for the student or staff

Table 1.8Clinical and public health guideline for the diagnosis, treatment and prevention of typhoid fever

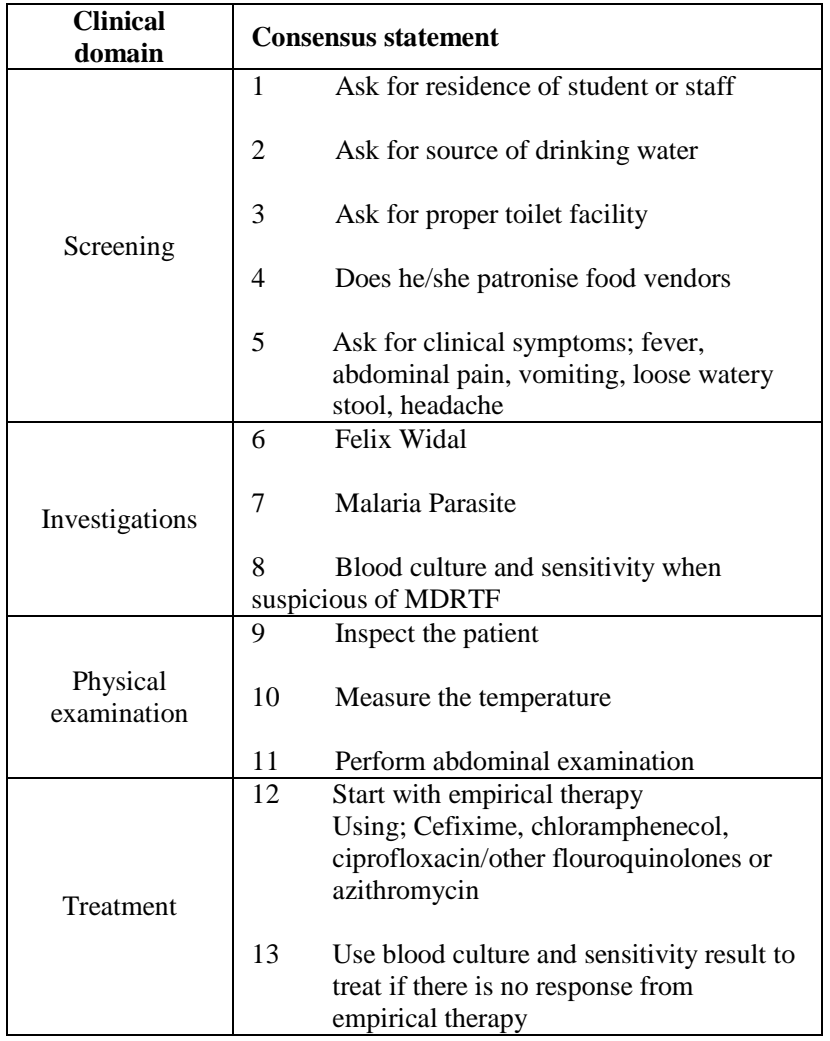




\begin{tabular}{|c|cl|}
\hline $\begin{array}{c}\text { Public health } \\
\text { intervention }\end{array}$ & 14 & $\begin{array}{l}\text { Advice patient on the need for clean safe } \\
\text { Drinking water and food (NAFDAC } \\
\text { registered sachet and bottled water /food) } \\
\text { as well as avoidance of self-medication }\end{array}$ \\
15 & $\begin{array}{l}\text { Recommend typhoid fever vaccination } \\
\text { when patient recover }\end{array}$ \\
\hline
\end{tabular}

\section{LIST OF REFERENCES}

[1] Adabara, NU, Ezugwu, BU, Momojimoh, A, Madzu, A, Hashiimu, Z, Damisa, D. 2012. The prevalence and antibiotic susceptibility pattern of Salmonella typhi among patients attending a Military Hospital in Minna, Nigeria. Advances in Preventive Medicine:1-4.

[2] Adefioye, T. 2014. Reliability and validity. From: https://docplayer.net/29708739-Reliability-and-validity-temiladeadefioye.html (accessed 25 August 2018).

[3] Akinyemi, KO, Oshundare, YO, Oyeyinka, OG \& Coker, AO. 2012 A retrospective study of community-acquired Salmonella infections in patients attending public hospitals in Lagos, Nigeria. Journal of Infection in Developing Countries 6:387-395.

[4] Anol, B. 2012. Social science research: Principles, methods and practices. Florida: Tampa

[5] Breiman, RF, Cosmas, L \& Njuguna, H. 2012. Population based incidence of typhoid fever in an urban informal settlememt and a rural area in Kenya: Implication for typhoid vaccine use in Africa. PLOS One 7(1):e29119.

[6] Brusch, JL. 2018. Typhoid Fever medication, edited by Bronze MS. From: https://emedicine.medscape.com/article/231135medication\#1 (accessed 26 August 2018).

[7] Buckle, GC, Walker, CL \& Black RE. 2012. Typhoid fever and paratyphoid fever: Systematic review to estimate global morbidity and mortality for 2010. Journal of Global Health 2:10401.

[8] Burns, N, Grove, SK. 2011. Understanding nursing research. $5^{\text {th }}$ edition. Saunders: Phildelphia.

[9] Butler, T. 2011. Treatment of typhoid fever in the 21st century: Promises and shortcomings. Clinical Microbiology and Infection 17:959-963.

[10] Capoor, MR \& Nair, D. 2010. Quinolone and Cephalosporin Resistance in Enteric Fever. Journal of Global Infectious Diseases 2(3):258-262.

[11] Cardona-Castro, NM, Sanchez-Jimenez, MM \& Usuga-Silva, LY. 2007. Characterization of two typhoid fever outbreaks in Apartado, Antioquia. Biomedica 27:236-243.

[12] Center for Disease Control and Prevention. 2017. Typhoid and paratyphoid fever.

[13] From; https://wwwnc.cdc.gov/travel/yellowbook/2018/infectiousdisease-related-to-travel/typhoid-paratyphoid-fever (accessed 30 August 2018).

[14] Chau, TT, Campbell, JI \& Galindo, CM. 2007. Antimicrobial drug resistance of Salmonella enterica serovar Typhi in Asia and molecular mechanism of reduced susceptibility to the $\mathrm{fl}$ uoroquinolones. Antimicrobial Agents and Chemotherapy 51:4315-4323.

[15] Chheng, K, Carter, MJ \& Emary, K. 2013. A prospective study of the causes of febrile illness requiring hospitalization in children in Cambodia. PLoS One 8:e60634.

[16] Choudhary, A, Gopalakrishnan, R, Nambi, PS, Ramasubramanian, V, Abdulghafur, K \& Thirunarayan, MA. 2013. Antimicrobial susceptibility of Salmonella entrica serovars in a tertiary care hospital in southern India. Indian Journal of Medical Research 137(4):800-802.

[17] Collins, H. 2010. Creative research: The theory and practice of research for the creative Industries. London, GBR: AVA.

[18] Crump, JA, Luby, SP \& Mintz, ED. 2004. The global burden of typhoid fever. Bulletin of World Health Organization 82:346-353.

[19] Crump, JA \& Mintz, ED. 2010. Global trends in Typhoid and Para typhoid fever. Clinical Infectious Diseases 50:241-246.
[20] Crump, JA, Ramadhani, HO \& Morrissey, AB. 2011. Invasive bacterial and fungal infections among hospitalized HIV-infected and HIV-uninfected children and infants in northern Tanzania. Tropical Medicine and International Health 16:830-837.

[21] Debois, S. 2016. Advantages and disadvantages of questionnaires. From: https://surveyanyplace.com/questionnaire-pros-and-cons/ (accessed 15 August 2018)

[22] Deen, J, Von Seidlein, L, Andersen, F, Elle, N, White, NJ \& Lubell ,Y. 2012. Community-acquired bacterial bloodstream infections in developing countries in south and southeast Asia: a systematic review. Lancet Infectious Diseases 12:480-487.

[23] DeRoeck, D, Ochiai, RL, Yang, J, Anh, DD, Alag, V \& Clemens JD. 2008. Typhoid vaccination: the Asian experience. Expert Review of Vaccines 7:547-560.

[24] Dictionary of Medical Terms. 2007. Sv "context". $4^{\text {th }}$ edition. London: A \& C Black.

[25] Dimitrov,T, Dashti, AA, Albaksami, O \& Jadaon, MM. 2010. Detection of mutations in the gyrA gene in $\mathrm{fl}$ uoroquinolone resistance Salmonella enterica serotypeS Typhi and paratyphi A isolated from the Infectious Diseases Hospital, Kuwait. Journal of Clinical Pathology 63:83-87.

[26] Dongol, S, Thompson, CN \& Clare S. 2012. The microbiological and clinical characteristics of invasive Salmonella in gallbladders from cholecystectomy patients in Kathmandu, Nepal. PLoSOne 7:e47342.

[27] Enabulele, O \& Awunor, SN. 2016. Typhoid fever in a Tertiary Hospital in Nigeria: Another look at the Widal agglutination test as a preferred option for diagnosis. Nigerian Medical Journal 57(3):145-149.

[28] Feasey, NA, Archer, BN \& Heyderman, RS. 2010. Typhoid fever and invasive nontyphoid salmonellosis, Malawi and South Africa. Emerging Infectious Diseases 16:1448-1451.

[29] Gordon, MA. 2011. Invasive nontyphoidal Salmonella disease: epidemiology, pathogenesis and diagnosis. Current Opinion in Infectious Diseases 24:484-489.

[30] Hassan, B, Nahar, SG, Akter, L\& Abu Saleh, A. 2011. Antimicrobial sensitivity pattern of Salmonella typhi isolated from blood culture in a referral hospital. Bangladesh Journal of Medical Microbiology 05(01):16-20.

[31] Hutton, G. 2013. Global costs and benefits of reaching universal coverage of sanitation and drinking water supply. Journal of Water Health 11:1-12

[32] Ishaleku, D, Sar, TT \& Houmsou, RS. 2011. Salmonella typhi in a tertiary institution in Nasarawa State, Nigeria. Asian Pacific Journal of Tropical Medicine 4(2):137-139.

[33] Joshi, S \& Amarnath, SK. 2007. Fluoroquinolone resistance in Salmonella typhi and S Paratyphi A in Bangalore, India. Trans R Soc Trop Med Hyg 101:308-310.

[34] Kaurthe, J. 2013. Increasing antimicrobial resistance and narrowing therapeutics in typhoidal Salmonellae. Journal of Clinical Diagnostic Research 7:576-579.

[35] Keddy, KH, Sooka, A, Ismail, H, Smith, AM, Weber, I, Letsoalo, ME \& Harris, BN. 2011. Molecular epidemiological investigation of a typhoid fever outbreak in South Africa, 2005: the relationship to a previous epidemic in 1993. Epidemiology and Infection 139:1239-1245.

[36] Khan, MI, Ochiai, RL \& Soofi SB. 2012. Risk factors associated with typhoid fever in children aged 2-16 years in Karachi, Pakistan. Epidemiology and Infection 140:665-672.

[37] Kimberlin, CL \& Winterstein, AG. 2008. Validity and reliability of measurement instruments used in research. American Journal of Health-system pharmacy 65(23):2276-2284.

[38] Kovalenko, AN, Zhdanov, KV \& Volzhanin VM. 2011. Features of clinic, diagnostics and treatment of typhoid fever in young patients. Voeno-Meditsinskii Zhurnal 332:33-39.

[39] Kumar, Y, Sharma, A \& Mani, KR. 2011. Re-emergence of susceptibility to conventionally used drugs among strains of Salmonella Typhi in central west India. Journal of Infection in Developing Countries 5:227-230. 
[40] Levine, MM, Ferreccio, C \& Black, R. 1990. Large-scale field trial of Ty21 a live oral vaccine against typhoid in enteric -coated capsule formulation. Lancet 336:891-894.

[41] Lozano, R, Naghavi, M \& Foreman, K. 2012. Global and regional mortality from 235 causes of death for 20 age groups in 1990 and 2010: A systematic analysis for the Global Burden of Disease Study 2010. Lancet 380:2095-2128.

[42] Lugunya, O, Phoba, MF, Mundeke, SA, Bonebe, E, Mukadi, P, Muyembe, JJ, Verhaegen, J \& Jacobs, J. 2012. The diagnosis of typhoid fever in the Democratic Republic of Congo. Transaction of the Royal Society of Tropical Medicine and Hygiene 106(6):348-355.

[43] Marks, F, Adu-Sarkodie, Y \& Hunger, F. 2010. Typhoid fever among children, Ghana. Emerging Infectious Diseases 16:17961797.

[44] Maskey, AP, Basnyat, B, Thwaites, GE, Campbell, JI, Farrar, JJ \& Zimmerman, MD. 2008. Emerging trends in enteric fever in Nepal: 9124 cases confirmed by blood culture 1993-2003. Transaction of the Royal Society of Tropical Medicine and Hygiene 102:91-95.

[45] Mogasale, V, Maskery, B \& Ohiai, LR. 2014. Burden of typhoid fever in low-income and middle-income countries: a systematic, literature-based update with risk factor adjustment. The Lancet Global Health 2:570-580.

[46] Molyneux, S, Kamuya, D \& Madiega, PA. 2013. Field workers at the interface. From: https://doi.org/10.1111/dewb.1207 (accessed on 21 August 2018).

[47] Morita, M, Takai, N \& Terajima, J. 2010. Plasmid-mediated resistance to cephalosporins in Salmonella enterica serovar Typhi. Antimicrobial Agents and Chemotherapy 54:3991-3992.

[48] Mullen, PM. 2003. Delphi: myths and reality. Journal of Health Organization and Management 17:37-52.

[49] Muyembe-Tamfum, JJ, Veyi, J, Kaswa, M, Lunguya, O, Verhaegen, J \& Boelaert, M. 2009. An outbreak of peritonitis caused by multidrug-resistant Salmonella Typhi in Kinshasa, Democratic Republic of Congo. Travel Medicine and Infectious Disease 7:40-43.

[50] Naheed, A, Ram, PK \& Brooks, WA. 2010. Paratyphoid fever in a densely populated urban community, Dhaka, Bangladesh. International Journal of Infectious Diseases 14(suppl 3):e93-e99.

[51] National Committee for Clinical Laboratory Standards. 2005. Manual of antimicrobial susceptibility testing. Wayne, PA: The National Committee for Clinical Laboratory Standards:339-349.

[52] National Health Insurance Scheme. 2016. Patients medical record. Kaura Namoda. The National Health Insurance Scheme. NCCLS see National Committee for Clinical Laboratory Standards/National Health Service. 2018. Typhoid fever treatment. From: https://www.nhs.uk/conditions/typhoid-fever/treatment/ (accessed 28 August 2018)

[53] National Population Commission. 2006. Nigeria National census. Abuja: The National Population Commission. NHS see National Health Service.

[54] Ochiai, RL, Acosta, CJ \& Danovaro-Holliday, MC. 2008. A study of typhoid fever in five Asian countries: disease burden and implications for control. Bulletin of World Health Organization 86:260-268.

[55] Onyekwere, CA. 2007. Typhoid fever: Misdiagnosis or overdiagnosis. The Nigerian Medical Practitioner 51(4):76-79.

[56] Oxford Advanced Learner's Dictionary. 2001. Sv "Context". $6^{\text {th }}$ edition. Oxford, UK: Oxford University Press.

[57] Polit, DF \& Beck, CT. 2012. Nursing research: generating and assessing evidence for nursing practice. $9^{\text {th }}$ edition. Philadelphia: Wolters Kluwer Health/Lippincott Williams \& Wilkins.

[58] Poudel, S, Shrestha, SK, Pradhan, A, Akpota, B \& Mahato, M. 2014. Antimicrobial susceptibility pattern of entrica species in Blood Culture Isolates. Clinical Microbiology 3(141):1-4.

[59] Powell, C. 2003. The Delphi technique: Myths and realities. Journal of Advanced Nursing 41(4):376-882.

[60] Prabhat, P \& Pandey, MM. 2015. Research methodology: Tools and techniques. $1^{\text {st }}$ edition. Romania: Bridge Center.
[61] Puyan, N. 2014. Pasteur, A chemistry graduate who revolutionalized the medicine. Journal of Microbiology Research 4(3):148-151.

[62] Rather, IA, Kim, BC, Vivek, K, Bajpai, VK \& Park, YH. 2017. Saudi Journal of Biological Sciences 24(4):808-812.

[63] Robinson, JBL. 2004. Delphi methodology for economic impact assessment. Journal of Transportation Engineering 117:335-349.

[64] Rotimi, VO, Jamal, W, Pal, T, Sovenned, A \& Albert, MJ. 2008. Emergence of CTX-M-15 type extended-spectrum beta-lactamaseproducing Salmonella spp. in Kuwait and the United Arab Emirates. Journal of Medical Microbiology 57: 881-886.

[65] Sawyerr, PT \& Yusof, N. 2013. Student satisfaction with hostel facilities in Nigerian polytechnics. Journal of Facilities Management 11(4):306-322.

[66] Setia, MS. 2016. Methodology Series Module 3: Cross-sectional Studies. Indian Journal of Dermatology 61(3):261-264.

[67] Singh, AS. 2014. Sampling techniques and determination of sample size in applied statistics research. From: https://www.ijecm.co.uk > uploads (accessed on 17 August 2018).

[68] Smith, AM, Keddy, KH \& Ismail H. 2011. For the Group for Enteric, Respiratory and Meningeal Disease Surveillance in South Africa (GERMS-SA). International collaboration tracks typhoid fever cases over two continents from South Africa to Australia. Journal of Medical Microbiology 60:1405-1407.

[69] Somily, AM, Sayyed, SB \& Habib, HA. 2012. Salmonella isolates serotypes and susceptibility to commonly used drugs at a tertiary care hospital in Riyadh, Saudi Arabia. Journal of Infection in Developing Countries 6:478-482.

[70] Song, J, Willinger, T \& Rongvaux A. 2010. A mouse model for the human pathogen Salmonella Typhi. Cell Host Microbe 8:369376.

[71] Starki, M, Brunner, N \& Stenstrom, TA. 2013. Why do water and sanitation systems for the poor still fail? Policy analysis in economically advanced developing countries. Environmental Science and Technology 47:6102-6110.

[72] Tacket, CO, Ferreccio, C, Robbins, JB, Tsai, CM, Schulz, D, Cadoz, M, Goudeau, A \& Levine, MM. 1986. Safety and immunogenicity of two Salmonella typhi Vi capsular polysaccharide vaccines. Journal of Infectious Diseases 154(2):342-345.

[73] Tabu, C, Brieman, RF, Ochieng, B, Aura, B, Cosmas L, Audi, A, Olack, B, Bigogo, G, Ongus, JR, Fields, P, Mintz, E, Burton, D, Oundo, J, \& Feikin, DR . 20012. Differential burden and epidemiology of non-typhi salmonella bacteremia in a rural and urban Kenya, 2006-2009. PLOS One 7(2):e31237.

[74] Talbot, LA. 1995. Principles and practice of nursing research. Mosby: Missouri.

[75] Tatavarthy, A, Sanderson, R \& Peak, K. 2012. Molecular typing and resistance analysis of travel-associated Salmonella enterica serotype Typhi. Journal of Clinical Microbiology 50:2631-2638.

[76] Thangaratinam, S \& Redman, CWE. 2005. Delphi technique. The Obstetrician and Gynaecologist 7(2):120-122.

[77] Thatcher, RW. 2010. Validity and reliability of quantitative electroencephalography (qEEG). Journal of Neurotherapy 14:122152.

[78] Thomas, PY. 2010. Research methodology and design - Unisa institutional repository. From: https://www.uir.unisa.ac.za>bitstream $>$ handle $>05$ (accessed 10 August 2018).UNESCO see United Nations Educational, cientific and Cultural Organization. UNICEF see United Nations International Children's Emergency Fund.

[79] United Nations International Children's Emergency Fund. 2013. Water, sanitation, and hygiene; Nigeria - The situation. Nigeria: UNICEF.

[80] United Nations Educational, Scientific and Cultural Organization. 2013. Nigeria-School enrolment. Nigeria: UNESCO Publications.

[81] University of South Africa. Department of Health Studies. 2018. General tutorial letter for proposal, dissertation, and thesis writing. Tutorial Letter 301/0/2018. Pretoria.

[82] Wain, J, Hendriksen RS, Mikoleit ML, Keddy KH, Ochiai RL. 2015. Typhoid Fever. Lancet 385:1136-1145. 
[83] Weber, E. 2011. Autonomy and informed consent: medical research ethics. From: https://www.slideshare.net/mobile/eliweber1980/automomy-andinformed-consent (accessed 26 August 2018) WHO see World Health Organization.

[84] World Health Organization. 2003. Background document: The diagnosis, treatment and prevention of typhoid fever. Geneva: WHO.

[85] Zaki, SA \& Karande S. 2011. Multidrug-resistant typhoid fever: A review. Journal of Infection in Developing Countries 5:324-337. 